\title{
PODERES E ATUAÇÕES DO SECRETARIADO E DO SECRETÁRIO-GERAL DA ONU NAS IMPLICAÇÕES CONCEITUAIS E NA EFETIVIDADE DA TEORIA RESPONSIBILITY TO PROTECT
}

\section{POWERS AND ACTIVITIES OF THE SECRETARIAT AND THE UN SECRETARY - GENERAL ON THE CONCEPTUAL IMPLICATIONS AND EFFECTIVENESS OF RESPONSIBILITY TO PROTECT THEORY}

${ }^{1}$ Flávia de Ávila

\section{RESUMO}

A doutrina Responsibility to Protect (R2P), implementada no âmbito da ONU, é uma reação a graves acontecimentos vivenciados pela sociedade internacional em que guerras são responsáveis pela morte e pelo deslocamento forçado de milhares de pessoas. Este conceito, que foi feito em resposta aos apelos do Secretário-Geral da ONU e resulta dos esforços empreendidos pelo Secretariado, é constantemente debatido pelos Estados-membros da organização, pois as várias tentativas, inclusive jurídicas, de se conter a violência em grande escala, dentre as quais se destaca para fins deste artigo o R2P, não se apresentam suficientes para impedir ou por vezes apenas apaziguar a ferocidade da guerra, que fica condicionada de muitas maneiras a fatores ligados ao exercício do poder e da influência dos atores no âmbito internacional. De tal modo, para que o objetivo geral deste breve ensaio possa ser alcançado, que se refere ao entendimento acerca de poderes e atuações do Secretariado e do SecretárioGeral da ONU sobre as formulações conceituais do Responsibility to Protect e sua efetividade, será necessário que haja o aprofundamento de pontos como o estudo dos atributos e competências do Secretariado e do Secretário-Geral da ONU, o desenvolvimento conceitual do R2P e a breve menção de algumas situações em que houve ou que poderia haver sua aplicação, como nos casos queniano e sírio, a fim de que seja entendida melhor a sua efetividade. A pesquisa, feita de maneira interdisciplinar entre os campos do conhecimento do Direito e das Relações Internacionais, interliga por meio de seus objetivos geral e específicos, temas relacionados ao cotidiano das relações internacionais e do direito internacional, como solução pacífica de controvérsias, teoria das organizações internacionais, intervenções humanitárias e soberania estatal. Como método científico, o método indutivo é utilizado para que a problematização correspondente ao R2P possa evidenciar poderes e atribuições do Secretariado e do Secretário-Geral da ONU, bem como suas limitações. Utiliza-se, ainda, da vertente metodológica jurídico-dogmática ou jurídico-teórica, que analisa normas jurídicas específicas em relação às demais normativas do ordenamento jurídico, não as considerando pura e simplesmente, mas as correlacionando com fontes externas que lhes são peculiares, bem como de método histórico-comparativo, utilizado para o entendimento dos institutos jurídicos e do desenvolvimento do Secretariado e do papel do Secretário-Geral. Enfatiza-se, portanto, que o estudo bibliográfico-documental não se centrará somente em documentos do Secretariado da ONU, mas também abrangerá resoluções do Conselho de Segurança, da Assembleia Geral, assim como interpretações doutrinárias.

\footnotetext{
${ }^{1}$ Doutora em Direito pela Pontifícia Universidade Católica de Minas Gerais - PUC Minas, Minas Gerais, MG, Brasil. Professora na Universidade Federal de Sergipe - UFS, Sergipe.E-mail: flaviadeavila@gmail.com.
} 
Palavras-chave: Responsibility to protect (R2P), Soberania estatal, Uso da força nas relações internacionais

\section{ABSTRACT}

The Responsibility to Protect doctrine (R2P), implemented in the UN, is a reaction to serious events experienced by international society in which wars are responsible for killing and for forced displacement of thousands of people. This concept, which was made in response to UN Secretary-General appeals and results of the efforts made by the Secretariat is constantly debated by the Member States of the organization, since several attempts, including legal, to contain violence on a large scale, among which stands out for purposes of this article the $\mathrm{R} 2 \mathrm{P}$, present themselves insufficient to prevent or sometimes just to appease the ferocity of the war, which is conditioned in many ways to factors relating to the use of power and influence by the actors in the international arena. Thus, for the general purpose of this brief essay might be achieved, which refers to the understanding of powers and activities of the Secretariat and UN Secretary-General on the conceptual formulations of the Responsibility to Protect and its effectiveness, will be necessary to research more profoundly some questions like the attributes and the powers of the Secretariat and the UN Secretary General, the conceptual development of the R2P and a brief mention of some situations where there has been or could be your application, as in the Kenyan and Syrian cases, order to be better understood its effectiveness. The survey, conducted in an interdisciplinary way between the fields of knowledge of Law and International Relations, connects through its general and specific objectives, issues related to the daily lives of international relations and international law, and peaceful settlement of disputes, organizational theory international, humanitarian intervention and state sovereignty. As the scientific method, the inductive method is used to evidence if the R2P can show how the Secretariat and the Secretary-General exercise their powers and duties, as well as its limitations. It is used also to legal-dogmatic or legal-theory method, which analyzes specific laws in relation to other regulations of the law correlating with external sources, as well as historical-comparative method used to understand the legal institutions and the development of the Secretariat and the Secretary-General's role. It emphasizes, therefore, that the bibliographical and documentary study will focus not only on UN Secretariat documents, but also cover the Security Council resolutions, the General Assembly, as well as doctrinal interpretations.

Keywords: Responsibility to protect (R2P), State sovereignty, Use of force in international relations 


\section{INTRODUÇÃO}

Por intermédio de órgãos internacionais ${ }^{1}$, que se configuram em elementos da estrutura de uma organização internacional pelos quais a vontade deste sujeito de direito internacional se expressa, a Organização das Nações Unidas (ONU) desempenha suas funções no âmbito internacional. Sendo considerada como organização de fins gerais ou políticos, os amplos objetivos da ONU, conforme determinados em seu próprio pacto constitutivo, somente podem ser implementados em razão de uma conjuntura de fatores que envolvem desde a definição de poderes e atribuições até o estabelecimento de estrutura organizacional básica, para que a organização possa atuar na resolução de conflitos internacionais e no agenciamento de relações pacíficas entre os seus membros.

Deste modo, faz-se imprescindível para a própria existência de uma organização internacional que ela possua caráter permanente e aparato burocrático que lhe comporte funcionar de maneira contínua em atividades relacionadas tanto com a tomada de decisões quanto com sua implementação. A existência de órgão com tais atribuições, normalmente uma secretaria com sede fixa e concernentes prerrogativas, permite que haja o exercício de atributos da personalidade jurídica das organizações internacionais. No caso da ONU, o Secretariado, um dos seus principais órgãos, segundo art. $7^{\circ}$ da Carta da $\mathrm{ONU}^{2}$, cumpre este papel, presidido pelo Secretário-Geral.

As atribuições do Secretário-Geral, contudo, suplantam as funções de mero dirigente do órgão administrativo da organização, em virtude de ser considerado o chefe da organização, conforme descrito no art. 97 da Carta da ONU. Ainda assim, apesar de o Secretário-Geral ter funções próprias, que transcendem inclusive sua atuação no âmbito do Secretariado, não se faz possível analisar tais figuras de maneira separada, pois o reconhecimento e o exercício da personalidade jurídica das organizações internacionais estão ligados diretamente à atuação e a responsabilização de seus funcionários ${ }^{3}$.

\footnotetext{
${ }^{1}$ Cf. SALMON, Jean (ed.). Dictionnaire de Droit International Public. Bruxelas : Bruylant, 2001, p. 790-791 apud CRETELLA NETO, José. Teoria Geral das Organizações Internacionais. São Paulo: Saraiva, 2007, p. 153.

${ }^{2}$ A redação do art. $7^{\circ}$ da Carta da ONU assim determina: " $\$ 1$. Ficam estabelecidos como órgãos principais das Nações Unidas: uma Assembleia Geral, um Conselho de Segurança, um Conselho Econômico e Social, um conselho de Tutela, uma Corte Internacional de Justiça e um Secretariado. §2. Serão estabelecidos, de acordo com a presente Carta, os órgãos subsidiários considerados de necessidade".
} 
A estrutura complexa do Secretariado da ONU exemplifica uma forma fracionada de estrutura organizacional, pela qual departamentos e escritórios foram criados para atuarem em diferentes linhas de ação, organizados conforme características de complementariedade e similaridade. Estes órgãos estão a cargo de nomeados sêniores ou de alto nível, que respondem ao Secretário-Geral. Este, por sua vez, apesar de possuir prerrogativas genéricas descritas no Cap. XV da Carta da ONU (arts. 98 a 101), teve suas atribuições alteradas pela prática em função das tensões do cenário internacional e da significativa atuação exercida desde seus primeiros Secretários-Gerais em episódios marcantes das relações internacionais. Desta forma, a maneira como opera o Secretário-Geral repercute tanto dentro do sistema jurídico-político da ONU quanto na relação com seus membros.

É importante ressaltar que as atuações do Secretariado e do Secretário-Geral na aplicação de meios de solução pacífica de controvérsias e em missões de paz têm se desenvolvido no decorrer dos setenta anos de existência da ONU e sido cada vez mais frequentes. Mais recentemente, os últimos Secretários-Gerais tiveram a preocupação em estabelecer parâmetros para a ocorrência de intervenções humanitárias em razão de graves e sistemáticas violações de direitos humanos.

Em 2000, Kofi Annan ${ }^{4}$, sensibilizado pelas crueldades promovidas em conflitos ocorridos Ruanda e na região dos Balcãs na década de 90, pronunciou-se em favor de medidas mais efetivas que impedissem tais acontecimentos. Em resposta ao pronunciamento, o relatório da Internacional Commission on Intervention and State Sovereignty (ICISS) estabeleceu bases para a discussão no âmbito da Assembleia Geral da ONU do conceito Responsibility to Protect $(\mathrm{R} 2 \mathrm{P})$, que repercute diretamente sobre questões relacionadas à soberania dos Estados. O R2P foi posteriormente consolidado no Documento Final da Cúpula Mundial (World Summit ${ }^{5}$ ), que o restringiu aos crimes de guerra, genocídio, crimes contra a humanidade e limpeza étnica.

Ban Ki-moon deu continuidade ao tema ao se referir nele em documentos de 2009 e 2012, dotando o conceito de bases fundamentais. No relatório de 2009, o atual Secretário-

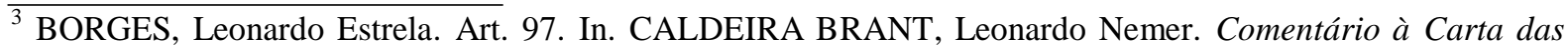
Nações Unidas. Belo Horizonte: CEDIN, 2008, p. 1161.

${ }^{4}$ ANNAN, K. We the peoples: the role of the United Nations in the 21st Century. New York: United Nations, 2000.

${ }^{5}$ Conforme os $\S \S 138$ e 139 do Documento Final da Cúpula Mundial. ORGANIZAÇÃO DAS NAÇÕES UNIDAS. World Summit Outcome. $2005 . \quad$ Disponível em<http://www.responsibilitytoprotect.org/UNSG\%20Report_timely\%20and\%20decisive\%20re Acesso em: 8 Jun. 2015.
} 
Geral da ONU estabeleceu que o R2P deveria se consolidar em três pilares: a responsabilidade primária do Estado na proteção da população; a responsabilidade internacional para o uso de meios pacíficos para a proteção da população dos Estados; e a possibilidade de ação coletiva internacional quando verificada a incapacidade dos Estados envolvidos em proteger sua população ${ }^{6}$. Em 2012, no Relatório Final do Secretário Geral da ONU, Responsabilidade de proteger: resposta em tempo hábil, foi acolhida em parte do texto uma vertente apresentada pela diplomacia brasileira, Responsibility while Protecting (RwP), que alerta a sociedade internacional das várias implicações, inclusive as consideradas calamitosas, que podem vir a ocorrer por intermédio intervenções que atuem em detrimento da própria população local ${ }^{7}$.

Não obstante, apesar desses esforços, as questões que cercam o escopo jurídico e político envolvendo as missões de paz e as consequências das intervenções nas soberanias estatais ainda estão a mercê de forças que superam os poderes do Secretário-Geral e do Secretariado da ONU. Assim, a aplicação do R2P encontra-se atualmente em um impasse que depende diretamente das forças políticas atuantes nas relações internacionais para ser solucionado. Esta é a justificativa que se refere à oportunidade da pesquisa, que se torna relevante na atualidade em vista da necessidade de se entender as razões possibilitam uma intervenção juridicamente permitida na soberania dos Estados em virtude do desrespeito aos direitos humanos.

Os graves acontecimentos vivenciados pela sociedade internacional em que guerras como a que está sendo travada em solo sírio são responsáveis pela morte e pelo deslocamento forçado de milhares de pessoas ajudam a evidenciar o critério de validade que justifica este estudo. Isto porque, as várias tentativas, inclusive jurídicas, de se conter a violência em grande escala, dentre as quais se destaca para fins deste artigo o R2P, não se apresentam suficientes para impedir ou por vezes apenas apaziguar a ferocidade da guerra, que fica condicionada de muitas maneiras a fatores ligados ao exercício do poder e da influência dos atores no âmbito internacional.

De tal modo, para que o objetivo geral deste breve ensaio possa ser alcançado, que se refere ao entendimento acerca de poderes e atuações do Secretariado e do Secretário-Geral da

${ }^{6}$ Cf. BAN, K. M. Report of the Secretary General - Implementing the Responsibility to Protect. 2009. Disponív em:

$\leq$ http://www.responsibilitytoprotect.org/index.php? module=uploads\&func=download\&fileId=655>. Acesso em: 12 Jun. 2015.

${ }^{7}$ Cf. BAN, K. M., Report of the Secretary General - Responsibility to protect: timely and decisive response. 2012. 
ONU sobre as formulações conceituais do Responsibility to Protect e sua efetividade, será necessário que haja o aprofundamento de pontos relacionados nesta introdução que se constituem em objetivos específicos. Estes, que melhor delimitam o caminho metodológico a ser percorrido para a consecução do objetivo geral, referem-se ao estudo dos atributos e competências do Secretariado e do Secretário-Geral da ONU, ao desenvolvimento conceitual do R2P e da breve menção de algumas situações em que houve ou que poderia haver sua aplicação, como nos casos queniano e sírio, a fim de que seja entendida melhor a sua efetividade.

A pesquisa, feita de maneira interdisciplinar entre os campos do conhecimento do Direito e das Relações Internacionais, interliga por meio de seus objetivos geral e específicos, temas relacionados ao cotidiano das relações internacionais e do direito internacional, como solução pacífica de controvérsias, teoria das organizações internacionais, intervenções humanitárias e soberania estatal. Como método científico, o método indutivo é utilizado para que a problematização correspondente ao R2P possa evidenciar poderes e atribuições do Secretariado e do Secretário-Geral da ONU, bem como suas limitações. Utiliza-se, ainda, da vertente metodológica jurídico-dogmática ou jurídico-teórica, que analisa normas jurídicas específicas em relação às demais normativas do ordenamento jurídico, não as considerando pura e simplesmente, mas as correlacionando com fontes externas que lhes são peculiares ${ }^{8}$, bem como de método histórico-comparativo, utilizado para o entendimento dos institutos jurídicos e do desenvolvimento do Secretariado e do papel do Secretário-Geral. Enfatiza-se, portanto, que o estudo bibliográfico-documental não se centrará somente em documentos do Secretariado da ONU, mas também abrangerá resoluções do Conselho de Segurança, da Assembleia Geral, assim como interpretações doutrinárias.

\section{SECRETARIADO DA ONU: DESENVOLVIMENTO, FUNÇÕES E ATRIBUIÇÕES}

A conformação orgânica inicial das organizações internacionais se deu principalmente em função da existência de um órgão com atribuições administrativas, identificado com uma secretaria que atuava de maneira burocrático-administrativa, sem que fossem exercidas funções políticas.

${ }^{8}$ GUSTIN, M. B. S.; DIAS, M. T. F. (Re) Pensando a Pesquisa Jurídica: teoria e prática. 4. ed. Belo Horizonte: Editora Del Rey, 2013, p. 20-25.

${ }^{9}$ CRETELLA NETO, José. Teoria Geral das Organizações Internacionais. São Paulo: Saraiva, 2007, p. 18-25. 
Estas, surgidas no séc. XIX e classificadas pela teoria das organizações internacionais como sendo as de primeira geração ${ }^{9}$, não possuíam personalidade jurídica própria e atuavam apenas acerca de competências técnicas, científicas e econômicas. Com parcos recursos financeiros, tinham reduzido pessoal, mas funcionavam de maneira permanente e eram presididas por um diretor que respondia pelo bom andamento de seus trabalhos ${ }^{10}$. Durante o decorrer do séc. XIX, tiveram diferentes finalidades e englobaram as comissões fluviais (que facilitavam acordos de navegação no Reno e no Danúbio), as comissões sanitárias (que procuravam conter epidemias), as uniões administrativas (que incentivavam a cooperação em questões tecnológicas e de comunicação) e as comissões financeiras (que administravam a dívida de Egito e Grécia) ${ }^{11}$.

A Liga das Nações, surgida após o término da Primeira Guerra Mundial, fruto das discussões e das teorias defendidas na Conferência de Paz de Paris que resultaram no Tratado de Versalhes, de 1919, tinha objetivos mais complexos que suas antecessoras. Conforme o Pacto da Liga das Nações (que correspondia a uma parte do Tratado de Versalhes) determinava, dentre outros propósitos, a adoção de sistema de segurança coletiva baseado em resolução de disputas internacionais por via diplomática, arbitral ou judicial, assim como desarmamento e garantias mútuas de políticas independentes e integridade territorial entre todos os Estados ${ }^{12}$. A Organização Internacional do Trabalho (OIT), também criada pelo Tratado de Versalhes, também se fundava em objetivos abrangentes. Com base em parâmetros internacionais de justiça social, propugnava o desenvolvimento e a harmonização de legislação protetiva ao trabalhador que impedisse condições degradantes de trabalho e evitasse conflitos sociais que ameaçassem a paz $^{13}$.

Nesta segunda geração, exigiu-se que houvesse estrutura orgânica mais complexa, como o exemplo do estipulado pelo art. $2^{\circ}$ do Pacto da Liga das Nações, na qual a Assembleia e o Conselho seriam auxiliados por uma Secretaria permanente. Este é, certamente, um fato marcante em relação às organizações internacionais, pois não havia experiências precedentes que embasassem o funcionamento de uma secretaria que atuasse de acordo com objetivos tão ambiciosos.

\footnotetext{
${ }^{10}$ CRETELLA NETO, José. Teoria Geral das Organizações Internacionais. São Paulo: Saraiva, 2007, p. 25-26.

${ }^{11}$ CRETELLA NETO, José. Teoria Geral das Organizações Internacionais. São Paulo: Saraiva, 2007, p. 22-26; MALANCZUK, Peter. Akhurst's Modern Introduction to International Law. 7 ed. Londres: Routledge, 1997, p. 22.

${ }^{12}$ MACMILlan, Margaret. Paz em Paris: a Conferência de Paris e seu Mister de Encerrar a Grande Guerra. Trad. Joubert de Oliveira Brízida. Rio de Janeiro: Nova Fronteira, 2004, p. 111.

${ }^{13}$ MACMILlAN, Margaret. Paz em Paris: a Conferência de Paris e seu Mister de Encerrar a Grande Guerra. Trad. Joubert de Oliveira Brízida. Rio de Janeiro: Nova Fronteira, 2004, p. 111-112.
} 
$\mathrm{O}$ art. $6^{\circ}$ do Pacto da Liga das Nações previu a figura de um Secretário Geral e de secretários, além de pessoal necessário para o funcionamento da Secretaria permanente. Inicialmente moldada de acordo com o serviço civil britânico, que previa a distribuição de tarefas dos escalões mais baixos para os mais altos, em razão de o seu primeiro SecretárioGeral ter sido o inglês Eric Drummond, tomou o exemplo do sistema administrativo francês, centralizado e baseado na tomada de decisões de cima para baixo, a partir do mandato do francês Joseph Avenol, iniciado em $1933^{14}$.

Apesar de não ser enumerada no Pacto da Liga das Nações como órgão principal, a prática adotada pela organização evidencia que a Secretaria permanente tornou-se responsável por supervisionar a apropriada implementação dos objetivos do Pacto da Liga das Nações, conforme relatórios de comitês apreciados pela Assembleia. ${ }^{15}$ Dentre as atividades políticas exercidas pela Secretaria permanente, estava a cargo do Secretário-Geral a apresentação de informações e relatórios aos delegados dos membros da Liga das Nações que versavam sobre ameaças imediatas à paz ${ }^{16}$.

A despeito da extinção da Liga das Nações, em 18 de abril 1946, na sua 21 Assembleia $^{17}$, suas bem sucedidas experiências em relação à ordenação estrutural de uma organização foram inspiradoras para a criação da ONU, que possui estrutura ainda mais robusta em relação àquela presente na sua antecessora, com o Secretariado figurando dentre os órgãos principais da organização. A ênfase no papel do Secretariado se deveu em razão de discussões que permearam a criação a Carta da ONU, nas quais duas correntes distintas se destacavam acerca das atribuições dadas ao seu funcionário mais graduado.

De acordo com a teoria vencedora, o superestatismo, um único indivíduo ocuparia a posição de Secretário-Geral, o que a diferencia do interestatismo, que previa a existência de outros secretários que representassem tendências políticas, econômicas e sociais distintas, assim como havia no âmbito da Liga das Nações. Todavia, já em 1946, o então Secretário-

\footnotetext{
${ }^{14}$ GINNEKEN, Anique H. M. Historical dictionary of the League of Nations. Lanham: The Scarecrow Press, 2006, p. 9-10.

${ }^{15}$ GINNEKEN, Anique H. M. Historical dictionary of the League of Nations. Lanham: The Scarecrow Press, 2006, p. 167-168.

${ }^{16}$ GORDENKER, Leon. The UN Secretary-General and Secretariat. 2 ed. Nova York: Routledge, 2010, p. 9.

17 LIGA DAS NAÇÕES. Assembleia. Resolução A.32(1).1946.X. General report of the Finance Committee, approved by the Finance Committee. 18 abr. 1946.

18 ORGANIZAÇÃO DAS NAÇÕES UNIDAS. Assembleia Geral. Resolução 13 (1). Organization of the

Secretariat. $14 \mathrm{fev}$ 1946. Disponível em: 1 lhttp://daccess-ddsny.un.org/doc/RESOLUTION/GEN/NR0/032/64/IMG/NR003264.pdf?OpenElement>. Acesso em: 16 jun. 2015.
} 
Geral Trygve Lie foi o responsável pela criação de cargos de assistentes para atuação em diversos assuntos ${ }^{18}$. A esta providência outras tantas se seguiram, em virtude principalmente das necessidades de ampliação das funções da ONU, bem como a complexidade da administração da organização. Novos cargos de direção, extremamente importantes para o funcionamento da ONU, foram instituídos, como de subsecretáriosgerais e do Vice

Secretário-Geral. Estes, por sua vez, atuam em órgãos subsidiários do Secretariado, cujas competências são delimitadas de acordo com o órgão principal que os criou.

\section{O SECRETÁRIO-GERAL DA ONU}

O Secretário-Geral, apesar de ocupar cargo de imenso prestígio, mas de poucos poderes, segundo análises de relações internacionais ${ }^{19}$, tem grande visibilidade mundial, o que lhe confere prerrogativas únicas. Sua escolha, de acordo com a Carta da ONU, mobiliza a Assembleia Geral e o Conselho de Segurança da ONU. Segundo o art. 97 da Carta da ONU, a eleição do Secretário-Geral se dará pela Assembleia Geral mediante a recomendação do Conselho de Segurança. De acordo com a regra 141 das Regras de Procedimento da Assembleia Geral, o Conselho de Segurança deve submeter sua recomendação à Assembleia Geral sobre a indicação do Secretário-Geral, que poderá aprová-la pelo voto em escrutínio realizado em reunião privada. Entretanto, é mais comum que haja aclamação.

Além das necessárias características relativas à idoneidade moral e capacidade laborativa que a responsabilidade da função exige ${ }^{20}$, o nome a ocupar o cargo deve necessariamente estar em consonância com os países que formam o chamado P5, ou seja, os cinco membros permanentes do Conselho de Segurança. A cada eleição, põe-se em movimento um exaustivo exercício diplomático para que haja consenso entre Estados Unidos, Reino Unido, França, China e Rússia, a fim de que concordem com o candidato. O quórum para a votação no Conselho de Segurança para questões importantes, de acordo com o art. 27 da Carta da ONU, é de nove votos, sendo que a aprovação só ocorrerá se um membro permanente não tiver exercido o direito de veto.

O posto de Secretário-Geral tem sido exercido de acordo com um processo informal que apresenta certa rotatividade, em que estão representados Europa Ocidental, Leste Europeu, América Latina e Caribe, Ásia e Pacífico e África. Contudo, o rodízio destes cinco grupos regionais não está devidamente especificado no âmbito dos tratados ou da regulamentação da ONU, nem determinado de maneira inequívoca pela prática. Foi invocado 
pela primeira vez pelos países latino-americanos nos anos 80 para que Javier Pérez de Cuéllar pudesse ser eleito. Em outra ocasião, que se refere à substituição de Boutros Boutros-Ghali, que não teve um segundo mandato, houve a aceitação de que outro africano o sucedesse, este sendo Kofi Annan. Até os dias atuais, não foi eleito Secretário-Geral do Leste Europeu e nenhuma mulher ocupou o cargo ${ }^{21}$.

A regra referente à duração do mandato ser de cinco anos, sendo possível uma recondução, não consta da Carta da ONU, mas está presente na Resolução da Assembleia Geral 11 (1), de 1946, que estipulou regras para a eleição do primeiro Secretário-Geral ${ }^{22}$. Estas, de maneira geral, foram seguidas posteriormente pelos Estados e são costumeiramente consideradas. A tentativa de Kurt Waldheim para se habilitar a um terceiro mandato foi rechaçada ${ }^{23}$.

O Secretário-Geral possui várias funções derivadas do fato de ser o funcionário mais graduado da organização bem como seu chefe administrativo. Assim, é institucionalmente e pessoalmente responsável pelo cumprimento dos objetivos da ONU. Apesar de haver apenas menção a uma atuação política do Secretário-Geral no art. 99 da Carta da ONU, pelo qual pode chamar a atenção do Conselho de Segurança para questões que venham ameaçar a paz, houve um significativo incremento de sua posição política, garantida por documentos internos da ONU, ainda que condicionada aos rumos em que seguem as relações internacionais ${ }^{24}$. Isto porque seguidamente o art. 98 da Carta da ONU foi interpretado de maneira abrangente em relação às funções do Secretário-Geral. De acordo com seu conteúdo, o Secretário-Geral deve atuar em todas as reuniões dos demais órgãos principais da ONU e também desempenha outras funções que tais órgãos venham a lhe atribuir ${ }^{25}$.

\footnotetext{
${ }^{19}$ LYNCH, Colum. The Race for U.N. Secretary-General is Rigged. Foreign Policy. 14. Nov. 2014. Disponível em: <http://foreignpolicy.com/2014/11/14/the-race-for-u-n-secretary-general-is-rigged/>. Acesso em: 12 jul. 2015.

${ }^{20}$ Algumas das prerrogativas pessoais do Secretário-Geral estão determinadas nas seguintes resoluções: ORGANIZAÇÃO DAS NAÇÕES UNIDAS. Assembleia Geral. Resolução 11 (1). Terms of Appointment of the Secretary General. 24 jan. 1946. Disponível em: <http://daccess-ddsny.un.org/doc/RESOLUTION/GEN/NR0/032/62/IMG/NR003262.pdf?OpenElement>. Acesso em: 12 jul. 2015; e ORGANIZAÇÃO DAS NAÇÕES UNIDAS. Assembleia Geral. Resolução 60/286. Revitalization of the General Assembly. 9 out. 2006. Disponível em: < http://www.securitycouncilreport.org/atf/cf/\%7B65BFCF9B6D27-4E9C-8CD3-CF6E4FF96FF9\%7D/SGE\%20ARES60\%20286.pdf>. Acesso em: 12 jul. 2015.
} 
Como exemplo da expansão dos poderes do Secretário-Geral pelos demais órgãos da ONU, em dezembro de 1991, por meio da resolução 46/59, a Assembleia Geral adotou a Declaration on Fact-finding by the United Nations in the Field of the Maintenance of International Peace and Security, que determina os princípios pelos quais se obtém conhecimento de atos que tenham por consequência a ruptura da paz. Nela está estabelecido o papel do Secretário-Geral de monitorar questões relevantes sobre paz e segurança internacionais. As chamadas fact-finding missions podem ser empreendidas sob a responsabilidade do Conselho de Segurança, da Assembleia Geral ou do Secretário-Geral, que poderá convocar um grupo de experts para atuar sobre tais questões ${ }^{26}$.

Também serve para exemplificar a relevância da presença do Secretário-Geral em reuniões dos demais órgãos principais da ONU, a regra 13 das Regras de Procedimento da Assembleia Geral, que estipula que sua agenda provisória para as sessões ordinárias deve incluir o Relatório do Secretário-Geral sobre o Trabalho da ONU. Costuma ter especial relevância o Annual Report of the Secretary-General on the Work of the Organization, já utilizado como veículo para análise do cenário internacional por antigos Secretários-gerais. Contudo, Kofi Annan preferiu apenas relacionar os programas do Secretariado, o que foi seguido por seu sucessor, Ban Ki-moon. Entretanto, ambos preferiram se utilizar da palavra “eu” para sinalizar suas considerações pessoais acerca do conteúdo desses documentos ${ }^{27}$.

\footnotetext{
${ }^{1}$ Foram, até o presente momento, 8 Secretários-Gerais: 1) Trygve Halvdan Lie, da Noruega, exerceu o mandato entre fevereiro de 1946 e abril de 1953. Demitiu-se antes do final de seu segundo mandato. 2) Dag Hammarskjold era chanceler sueco e exerceu a função entre abril de 1953 e setembro de 1961, quando morreu em um acidente de avião que sobrevoava a África. 3) U Thant, de Mianmar, antiga Birmânia, que exerceu como interino o cargo de novembro de 1961 a novembro de 1962 e depois como eleito até dezembro de 1971.4) Kurt Waldheim, austríaco, exerceu o cargo de janeiro de 1972 a dezembro de 1981. 5) Javier Pérez de Cuéllar, peruano que exerceu o mandato de janeiro de 1982 a dezembro de 1991.6) Butros Butros-Ghali, do Egito, exerceu o cargo de janeiro de 1992 a dezembro de 1996. 7) Kofi Annan, de Gana, foi funcionário internacional da ONU desde 1962, tendo exercido o mandato de janeiro de 1997 a dezembro de 2006. 8) Ban Ki-moon, que iniciou o mandato em janeiro de 2007 e terá seu segundo mandato terminado em dezembro de 2016.

${ }^{22}$ ORGANIZAÇÃO DAS NAÇÕES UNIDAS. Assembleia Geral. Resolução 11 (1). Terms of Appointment of the Secretary General. 24 jan. 1946. Disponível em: <http://daccess-ddsny.un.org/doc/RESOLUTION/GEN/NR0/032/62/IMG/NR003262.pdf?OpenElement>. Acesso em: 12 jul. 2015.

${ }^{23}$ GORDENKER, Leon. The UM Secretary-General and Secretariat. Londres: Routledge, 2010, p. 12.

${ }^{24}$ Como exemplo, em razão da Crise de Suez e da Guerra da Coréia, foram delegados poderes mais extensos tanto pelo Conselho de Segurança quanto pela Assembleia Geral, a Trygve Lie e Dag Hammarskjöld, os primeiros Secretários-Gerais da ONU. Outras delegações ocorreram em virtude do arrefecimento das hostilidades no oriente médio e no âmbito da guerra da Coréia. Estas delegações se repetiram após as tensões entre Israel e Egito terem aumentado em 1956 e com o estabelecimento de operações de peacekeeping no Congo (ONUC) entre 1960 e 1964.

${ }^{25}$ GORDENKER, Leon. The UN Secretary-General and Secretariat. Londres: Routledge, 2010, p. 20-21.
} 
No caso do Conselho de Segurança, a presença do Secretário-Geral se dá usualmente nas sessões abertas e nas discussões privadas. Nestas ocasiões, os documentos e relatórios de situações que envolvam ameaças à paz, rupturas da paz ou atos de agressão, bem como o andamento de missões de paz, são debatidos. São documentos em que normalmente está registrada a opinião do Secretário-Geral sobre os fatos

No campo administrativo, o Secretário-Geral atua nas esferas executiva, técnica e financeira, bem como zela pela gestão e organização do Secretariado. Dá suporte para os principais órgãos da $\mathrm{ONU}$, atuando em suas reuniões, confeccionando suas pautas provisórias e prestando serviços a conferências. Sobre este ponto, é importante salientar que a ONU se utiliza de seis línguas oficiais (árabe, chinês, inglês, francês, russo e espanhol), sendo que as línguas de trabalho e próprias para a interpretação são inglês e francês. Toda a documentação da organização deve ser produzida nas seis línguas oficiais e a preparação de reuniões de trabalho deve estar pelo menos em inglês e francês. A língua franca para a maioria das reuniões é o inglês. Durante as sessões, propostas governamentais e relatórios do Secretariado ou de órgãos intergovernamentais sobre os temas em discussão devem ser editados, traduzidos, reproduzidos e publicizados. As decisões devem ser gravadas e preservadas para a próxima sessão ${ }^{28}$.

O Secretário-Geral ainda opera no âmbito das comunicações tanto internas quanto as dirigidas ao público externo da organização, no monitoramento das decisões e recomendações tomadas pelos órgãos principais e na coordenação entre eles, bem como na integração dos mesmos às agências especializadas da ONU e respectivos programas operacionais. Um aspecto significante da coordenação de responsabilidades é o preparo da minuta do orçamento da ONU, que deve ser encaminhado ao Quinto Comitê ${ }^{29}$ e depois aprovado pela Assembleia Geral, conforme a regra 153 das Regras de Procedimento da Assembleia Geral.

\footnotetext{
${ }^{26}$ ORGANIZAÇÃO DAS NAÇÕES UNIDAS. Assembleia Geral. Resolução 46/59. Declaration on Fact-finding by the United Nations in the Field of the Maintenance of International Peace and Security. 9 dez. 1991. Disponível em: <http://www.un.org/documents/ga/res/46/a46r059.htm>. Acesso em: 12 jul. 2015.

${ }^{27}$ GORDENKER, Leon. The UN Secretary-General and Secretariat. Londres: Routledge, 2010, p. 19.
} 
A atuação do Secretariado em relação à governança global é dirigida pelo SecretárioGeral. Esta se consolida pela criação de políticas consensuais para regular as relações internacionais. São preparadas as bases para grandes conferências transnacionais sobre diversos temas, como população, direitos humanos, direitos da mulher e preservação do meioambiente, por exemplo. Tais conferências costumam produzir documento que determina princípios básicos e indicações de formas de implementação aprovadas pela maioria dos países participantes, mas que não têm caráter obrigatório. Para definir os temas que serão incluídos nas discussões das conferências e nas minutas de recomendações, o Secretariado consulta e requisita experts e associações profissionais de vários países, cujas sugestões são refinadas por comitês preparatórios. Estes eventos, normalmente conduzidos em cidades diferentes das cidades-sede da ONU, atraem representantes de diversos setores da sociedade civil, como Organizações Não-Governamentais ${ }^{30}$.

Politicamente, o Secretário-Geral exerce função representativa, o que lhe dá grande visibilidade internacional. Seus pronunciamentos e relatórios costumam chamar a atenção da opinião pública internacional e ajudar no estabelecimento de parâmetros para política global. Também compete a representar oficialmente a personalidade jurídica da ONU perante a sociedade internacional. Deste modo, é atribuída ao Secretário-Geral a conclusão de tratados, inclusive acordos de sede, bem como a gestão de fundos e contas em nome da organização ${ }^{31}$.

Outra forma de exercício da personalidade jurídica internacional da ONU está configurada pela Convenção sobre Privilégios e Imunidades das Nações Unidas ${ }^{32}$. A Convenção reconhece a personalidade jurídica da ONU para a consecução de seus objetivos, inclusive para contratar. Cabe ao Secretário-Geral a indicação daqueles que irão se beneficiar com a imunidade de jurisdição, sendo que tal categorização será submetida à Assembleia Geral, que comunicará aos Estados. As imunidades serão gozadas em relação a atos praticados no exercício de funções oficiais, o que inclui pronunciamentos tanto verbais quanto escritos. Também está prevista imunidade para peritos em missões, incluindo o tempo de.

\footnotetext{
${ }^{28}$ GORDENKER, Leon. The UN Secretary-General and Secretariat. Londres: Routledge, 2010, p. 18-19. A maior parte da documentação se encontra à disposição de consultas no site www.un.org.

${ }^{29}$ O Quinto Comitê trabalha com orçamento e aspectos administrativos, inclusive com operações de manutenção de paz. Com base em seus relatórios, a Assembleia Geral considera e aprova o orçamento da ONU, de acordo com o Cap. IV, art. 17, da Carta da ONU. Sua competência foi determinada pela Resolução 45/248B, Seção VI. ORGANIZAÇÃO DAS NAÇÕES UNIDAS. Assembleia Geral. Resolução 49/233A. 23 dez. 1994. Disponível em: 〈http://www.un.org/es/comun/docs/?symbol=A/RES/45/248>. Acesso em: 15 jun. 2015.

${ }^{30}$ GORDENKER, Leon. The UN Secretary-General and Secretariat. Londres: Routledge, 2010, p. 20.

31 ALMEIDA RIBEIRO, Ana Cristina; BORGES, Leonardo Estrela. Art. 98. In. CALDEIRA BRANT, Leonardo Nemer. Comentário à Carta das Nações Unidas. Belo Horizonte: CEDIN, 2008, p. 1193-1194.
} 
O Secretário-Geral, todos os sub-secretários gerais e dependentes gozão de direitos próprios aos agentes diplomáticos, que não são extensíveis para outros funcionários da ONU. Contudo, os privilégios e imunidades são concedidos unicamente no interesse da ONU e para que não haja vantagem pessoal. Assim, as imunidades poderão ser suspensas pelo Secretário Geral sempre que, em sua opinião, obstaculizem a justiça. No caso do Secretário-geral, o Conselho de Segurança tem competência para suspender as imunidades. Nos últimos anos, há sido intensificado o papel fiscalizatório da própria organização em relação à conduta ética dos funcionários da ONU, inclusive a do Secretário-Geral, que deve agir com transparência, imparcialidade e independência.

Em razão do extensivo uso na prática e da confirmação por várias resoluções da Assembleia Geral, o Secretário-Geral tem a autoridade para, se requisitado pelas partes ou autorizado pela Assembleia Geral ou pelo Conselho de Segurança, oferecer seus bons ofícios como meio de solução de controvérsias. Bons ofícios ou mediação por parte Secretário-Geral ou de seus representantes têm sido regularmente requisitados por Estados-membros ou pelo Conselho de Segurança. Contudo, até o final dos anos 80 do século passado, vários Secretários-Gerais por vezes utilizaram destas atribuições de ofício, como as sugestões de Tryeve Lie ante a crise de Berlim ou a sua proposição de bons ofícios na Guerra da Coréia. Com o fim da Guerra Fria e o aumento da participação da Assembleia Geral e do Conselho de Segurança nas ações de cooperação entre os Estados, este papel tornou-se mais limitado, cujo escopo de atuação é definido por delegações contidas nas resoluções dos órgãos envolvidos.

Um exemplo da aplicação de bons ofícios por diversos Secretários-Gerais da ONU em razão de uma situação de ruptura da paz é o caso cipriota, que se constitui atualmente uma das mais antigas missões de paz da ONU. Chamada United Nations Peacekeeping Force in Cyprus (UNFICYP), foi estabelecida sob a chefia do Secretário-Geral, com poderes para delegação destas atribuições a seu representante, para prevenir que mais violência fosse cometida entre comunidades cipriotas gregas e turcas por meio da resolução do Conselho de Segurança 186, de 1964. Após as hostilidades de 1974 que se seguiram ao golpe de estado em Chipre favorável à união com a Grécia e a tomada de controle da parte norte de Chipre pela Turquia, várias outras resoluções foram adotadas expandindo o mandato da UNIFCYP e os bons ofícios por parte do Secretário-Geral foram requisitados pelo Conselho de Segurança com os representantes das duas comunidades ${ }^{33}$.

IZAÇÃO DAS NAÇÕES UNIDAS. Assembleia Geral. Convenção sobre os Privilégios e Imunidades das Nações Unidas. 13 fev. $1946 . \quad$ Disponível em: $\quad<$ http://daccess-ddsny.un.org/doc/RESOLUTION/GEN/NR0/032/73/IMG/NR003273.pdf?OpenElement>. Acesso em 16 jun. 2015 


\section{O DESENVOLVIMENTO DO CONCEITO RESPONSIBILITY TO PROTECT NO ÂMBITO DA ONU}

Em 2000, o então Secretário-Geral da ONU, Kofi $\operatorname{Annan}^{34}$, deu um pronunciamento perante a Assembleia Geral da ONU no qual pedia que a comunidade internacional tomasse providências que pudessem impedir as carnificinas ocorridas durante os anos 90 do séc. passado, referentes ao genocídio em Ruanda e ao massacre de Srebrenica, na região dos Balcãs. Annan, que era funcionário internacional desde 1964, havia sido assistente do Secretário-Geral no Departamento de Operações de Manutenção de Paz (Peacekeeping Operations) durante o episódio ruandês, e reconheceu que não houve resposta adequada da sociedade internacional para estes eventos.

Em seu relatório, Annan procurou questionar o conceito de soberania frente à possibilidade de intervenção humanitária, entendendo que esta deveria ser uma preocupação da sociedade internacional como um todo. As críticas às intervenções, que poderiam servir de desculpa para a ingerência em assuntos internos dos Estados ou para a promoção de movimentos secessionistas foram correlacionadas pelo ex Secretário-Geral, seguidas de uma pergunta que apontava para um dilema ainda muito atual: se a intervenção humanitária é, de fato, um inaceitável ataque à soberania, como devemos responder a uma Ruanda, a uma Srebrenica, a graves e sistemáticas violações dos direitos humanos que ofenderam todos os preceitos de nossa humanidade comum ${ }^{35}$. Em resposta, Annan defendeu que princípio legal

\footnotetext{
33 ASMUSSEN, Jan. United Nations Peacekeeping Force in Cyprus (UNFICYP). In. KOOPS, Joachim; MACQUEEN, Norrie; TARDY, Thierry; WLIIAMS, Paul. The Oxford Handbook of United Nations Peacekeeping Operations. Oxford: Oxford University Press, 2015, p. 197-209.

${ }^{34}$ ANNAN, K. We the peoples: the role of the United Nations in the 21st Century. New York: United Nations, 2000. Disponível em: 〈http://www.un.org/en/events/pastevents/pdfs/We_The_Peoples.pdf>. Acesso em: 16 jul. 2015 .

35 A pergunta, no original em inglês, é a seguinte: "if humanitarian intervention is, indeed, an unacceptable assault on sovereignty, how should we respond to a Rwanda, to a Srebrenica - to gross and systematic violations of human rights that offend every precept of our common humanity?" ANNAN, K. We the peoples: the role of the United Nations in the 21st Century. New York: United Nations, 2000. Disponível em: <http://www.un.org/en/events/pastevents/pdfs/We_The_Peoples.pdf>. Acesso em: 16 jul. 2015.
} 
algum, nem mesmo a soberania, deveria servir para acobertar crimes contra a humanidade e que, uma vez esgotadas as tentativas de solução pacífica de controvérsias, caberia ao Conselho de Segurança o dever moral de agir em nome da comunidade internacional. Entretanto, intervenções armadas deveriam se constituir em último recurso, mas uma opção a não ser abandonada ${ }^{36}$.

Um conceito similar ao de Responsibility to Protect passou a ser desenvolvido pela União Africana (UA), que propôs o direito de intervenção em situações de crise, no caso de um Estado falhar em proteger sua população de atrocidades em massa, de acordo com o art. 4(h) do Ato Constitutivo da UA, de $2000^{37}$. Esta foi uma providência tomada como resposta da comunidade africana para prevenir casos como o Genocídio de Ruanda, de 1994, os conflitos ocorridos em virtude da independência da Namíbia, em 1990, dentre outros. A UA passou a adotar, por meio desse dispositivo, cultura de segurança baseada na não indiferença ${ }^{38}$, que influenciou diretamente o desenvolvimento do conceito do R2P no âmbito da $\mathrm{ONU}^{39}$.

Em setembro de 2000, atendendo ao apelo de Kofi Annan, o governo canadense estabeleceu a International Commission on Intervention and State Sovereignty (ICISS), com

\footnotetext{
${ }^{36}$ ANNAN, K. We the peoples: the role of the United Nations in the 21st Century. New York: United Nations, 2000. Disponível em: 〈http://www.un.org/en/events/pastevents/pdfs/We_The_Peoples.pdf〉. Acesso em: 16 jul. 2015.

37 Nas palavras do art. 4 (h) do Ato Constitutivo da UA, é “direito da União intervir num Estado Membro em conformidade com uma decisão da Conferência em situações graves nomeadamente, crimes de guerra, genocídio e crimes contra a humanidade" UNIÃO AFRICANA. Ato Constitutivo. Adotado pela trigésima-sexta sessão ordinária da Conferência dos Chefes de Estado da Organização da Unidade Africana. Lomé, 11 jul. 2000. Disponível em: <http://www.fd.uc.pt/CI/CEE/OI/OUA/acto_constitutivo-uniaoafricana.htm>. Acesso em: 15 jul. 2015.

${ }^{38}$ WILLIAMS, Paul D. From Non-Intervention to Non-Indifference: the origins and development of the African Union's Security Culture. African Affairs, vol.106/423, p. 253-279, 2007. Disponível em: <http://users.polisci.wisc.edu/schatzberg/ps362/Williams2007.pdf〉. Acesso em: 15 jul. 2015.

39 Algumas diferenças entre os institutos referidos pela UA e pela ONU se fazem presentes. Primeiramente, enquanto o R2P prevê a autorização da intervenção por meio do Conselho de Segurança da ONU, não há indicação da autoridade para implementar a intervenção no âmbito da UA. O R2P também determina que a intervenção somente ocorrerá se o Estado for manifestadamente incapaz ou não atuar na proteção de seus cidadãos. Contudo, na UA, não há necessidade de consenso para a intervenção sob o art. 4(h) do Ato Constitutivo da UA. Por fim, o art. 4 (h) do Ato Constitutivo da UA prevê uma obrigação legal, diferentemente do R2P, que é um comprometimento político. KUWALI, Dan. The African Union and the Challenges of Implementing the "Responsibility to Protect". Upsala: The Nordic Africa Institute, 2009. Disponível em: <http://www.nai.uu.se/publications/series/notes/978-91-7106-642-8.pdf>. Acesso em: 15 jul. 2015.

Em 2005, por intermédio do Common African Position on the Proposed Reform of the United Nations, conhecido como Esluwini Consensus, a UA acolheu a teoria do R2P como sendo uma importante ferramenta para a segurança coletiva e o uso da força por organizações regionais, vez que, muitas vezes, o Conselho de Segurança e a Assembleia Geral da ONU estão distantes dos acontecimentos que repercutem em violações dos direitos humanos das populações de seus Estados-membros. Uma vez autorizadas pelo Conselho de Segurança, estas operações de R2P conduzidas pelas organizações regionais, mesmo que ex post facto, deveriam ser financiadas pela ONU. GENSER, Jared; COTLER, Irwin. The Responsibility to Protect. Oxford: Oxford $\begin{array}{llll}\text { University } & \text { Press, } & \text { p. } & 215 .\end{array}$
} 
12 especialistas $^{40}$, a fim de que a pergunta feita pelo ex Secretário-Geral em seu pronunciamento pudesse ser respondida. A expressão Responsibility to Protect foi sugerida a fim de que fossem evitados termos como direito de intervir ou obrigação para intervir ${ }^{41}$. Esta expressão foi tomada a partir de Roberta Cohen e Francis Deng, que utilizaram a palavra responsabilidade para descrever a necessidade de ação estatal para proteção dos deslocados internos que se proliferaram em razão de conflitos após o fim da Guerra Fria, em um livro de $1998^{42}$.

Em casos ocorridos na década de 90, como no Kosovo de 1999, aprovada pela resolução 1244 do Conselho de Segurança da $\mathrm{ONU}^{43}$, causas humanitárias já tinham sido motivo para a interposição de operações de paz. No entanto, como mencionou o pronunciamento de Annan, a controvérsia entre soberania e intervenção humanitária sempre tornou polêmica essa questão, já que não estariam claras as delimitações da atuação da organização internacional frente aos obstáculos impostos ao princípio da não intervenção nos assuntos internos dos Estados, previsto no $\S 7^{\circ}$, art. $2^{\circ}$ da Carta da ONU, e da proteção internacional dos indivíduos que estivessem em situação de violação de seus direitos por parte de seus próprios Estados de origem.

O relatório de dezembro de 2001 da ICISS intitulado The Responsibility to Protect, o conceito de soberania foi questionado para que afastasse dos moldes da Paz de Westfália, de 1648, a fim de que os Estados exercessem uma soberania de responsabilidade, na qual é entendido como o principal responsável pela segurança humana. Haveria, portanto, um “direito de ingerência", que permitiria intervenção humanitária por parte de outros Estados em relação ao país considerado transgressor desta obrigação primária de proteger sua população local. A violação da soberania estaria justificada pela responsabilidade de proteger, que propugnaria pela permissão por parte da sociedade internacional em casos de negligência

\footnotetext{
40 A ICISS era presidida por Gareth Evans e Mohamed Sahnoun, e contava com a participação de Michael Ignatieff, Gisèle Côté-Harper, Lee Hamilton, Vladimir Lukin, Klaus Naumann, Cyril Ramaphosa, Fidel Ramos, Cornelio Sommaruga, Eduardo Stein e Ramesh Thakur. INTERNATIONAL COMMISSION ON INTERVENTION AND STATE SOVEREIGNTY. The Responsibility to Protect. Ottawa: International Development Research Centre, 2001. Disponível em: < http://responsibilitytoprotect.org/ICISS\%20Report.pdf>. Acesso em: 17 jul. 2015.

${ }^{41}$ GENSER, Jared; COTLER, Irwin. The Responsibility to Protect. Oxford: Oxford University Press, 2012, p. 64.

${ }^{42}$ COHEN, Roberta; DENG, Francis M. Masses in Flight: the global crisis of internal displacement. Washington: Brooking Institution Press, 1998.

43 ORGANIZAÇÃO DAS NAÇÕES UNIDAS. Conselho de Segurança. Resolução 1244. Adotada na $4011^{\mathrm{a}}$ Reunião. $10 \quad$ jun. $1999 . \quad$ Disponível $\quad$ em: $\quad<$ http://daccess-ddsny.un.org/doc/UNDOC/GEN/N99/172/89/PDF/N9917289.pdf?OpenElement>. Acesso em 17 jul. 2015.
} 
estatal, especificamente para genocídios, crimes contra a humanidade, crimes de guerra e limpeza étnica ${ }^{44}$.

De acordo com o relatório do ICISS, uma vez que o R2P fosse implementado, os interesses da população seriam protegidos sem que houvesse perda da soberania do Estado que sofresse uma intervenção, pois a soberania seria exercida pelo próprio povo, e não pelo governante que usurpasse seus direitos fundamentais. A consolidação dessa teoria também impediria que interesses de outros Estados prevalecessem em detrimento da proteção da população, visto que a intervenção seria legitimada pela defesa dos direitos humanos e do direito humanitário, o que facilitaria a acolhida por parte da sociedade internacional desta prática. Para tanto, esta medida seria excepcional, justificada apenas por causa justa, com a correta intenção, referente à diminuição ou prevenção do sofrimento humano. Seria também o último recurso, pois outras medidas afora a intervenção militar já teriam sido tentadas ou se presumiriam inúteis. Deveria se utilizar de meios proporcionais, que não excedessem o propósito da proteção humana, e que se constituíssem em prospectos razoáveis, com chances de se constituir em uma intervenção bem sucedida ${ }^{45}$.

Ainda foram acrescentadas justificativas jurídicas referentes a outros documentos para a que o R2P fosse entendido como instituto próprio da proteção humana, por meio de princípios baseados no chamado direito natural que estariam contidos na Carta da ONU, na Declaração Universal dos Direitos Humanos, de 1948, na Convenção das Nações Unidas para a Prevenção e Repressão do Genocídio, de 1946, nas Convenções de Genebra de 1949 e nos Protocolos Adicionais de 1977, bem como no Estatuto de Roma que estabeleceu o TPI, entre outros $^{46}$.

Em relação à compreensão deste novo conceito, o relatório estipulou os três tipos de responsabilidade para o R2P: prevenir, reagir e reconstruir. A prevenção é considerada a mais importante delas, pois abarcaria as causas dos conflitos e a capacidade de prever e combater crises. A segunda, correspondente à responsabilidade de reagir, seria aplicada no caso de falhas na prevenção, para que ocorresse uma intervenção que fosse aproximada da

44 INTERNATIONAL COMMISSION ON INTERVENTION AND STATE SOVEREIGNTY. The Responsibility to Protect. Ottawa: International Development Research Centre, 2001. Disponível em: $\langle$ http://responsibilitytoprotect.org/ICISS\%20Report.pdf>. Acesso em: 17 jul. 2015.

45 INTERNATIONAL COMMISSION ON INTERVENTION AND STATE SOVEREIGNTY. The Responsibility to Protect. Ottawa: International Development Research Centre, 2001. Disponível em: <http://responsibilitytoprotect.org/ICISS\%20Report.pdf>. Acesso em: 17 jul. 2015.

${ }^{46}$ BIERRENBACH, A. M. O conceito de responsabilidade de proteger e o Direito Internacional Humanitário. Brasília: FUNAG, 2011,p. 146. 
intervenção humanitária. Por fim, a responsabilidade de reconstrução, direcionada à paz e ao desenvolvimento ${ }^{47}$.

Em relação ao uso da força militar, o relatório determina apenas duas situações nas quais seria sua utilização seria permitida: no caso de haver a possibilidade de muitas vítimas, tanto reais quanto previsíveis, com ou sem a intenção genocida, como consequência de ação deliberada de um Estado, de sua negligência ou incapacidade de atuar, ou de seu colapso; ou no caso de limpeza étnica que tenha possibilidade de ocorrer em larga escala, real ou previsível, que ocorra mediante assassinato, expulsão forçada ou atos de terror ou estupro. $\mathrm{O}$ único órgão responsável pela implementação de ações militares baseadas no R2P seria o Conselho de Segurança da ONU, por ter poderes juridicamente determinado na Carta da ONU que pudessem manter e restaurar a paz, além de garantir a segurança internacional ${ }^{48}$.

Nos anos seguintes, essas discussões acerca do R2P foram reduzidas devido aos acontecimentos envolvendo o 11 de setembro de 2001, à Segunda Guerra do Golfo, que coincidiu com o lançamento do relatório da ICISS, e com a intervenção comandada pelos Estados Unidos no Iraque, em 2003. Neste ínterim, diante do plano de reformas internas da ONU colocado em curso lançado por Boutros-Gali, mas desenvolvido no mandato de Kofi Annan, houve a preocupação de se fortalecer a Assembleia Geral e o Secretariado, para que fossem criados mecanismos que pudessem melhor responder aos desafios novos e antigos vivenciados pela ONU, como o aumento das ações terroristas e a efetividade das operações de paz.

Uma comissão mundial, intitulada Painel de Alto Nível das Nações Unidas sobre Ameaças, Desafios e Mudança, foi instalada por Kofi Annan no final de 2003, presidida por Anand Payarachum, antigo primeiro ministro da Tailândia. Era composta por nomes de prestígio internacional, de diferentes nacionalidades ${ }^{49}$. Suas recomendações finais foram entregues em dezembro de 2004 com o nome de A More Secure World: our shared responsibility ${ }^{50}$. Este relatório tinha como ênfase a prevenção de ameaças à paz e à segurança

47 INTERNATIONAL COMMISSION ON INTERVENTION AND STATE SOVEREIGNTY. The Responsibility to Protect. Ottawa: International Development Research Centre, 2001. Disponível em: <http://responsibilitytoprotect.org/ICISS\%20Report.pdf>. Acesso em: 17 jul. 2015.

48 INTERNATIONAL COMMISSION ON INTERVENTION AND STATE SOVEREIGNTY. The Responsibility to Protect. Ottawa: International Development Research Centre, 2001. Disponível em: <http://responsibilitytoprotect.org/ICISS\%20Report.pdf>. Acesso em: 17 jul. 2015.

${ }^{49}$ Compunham o painel além de Anand Panyarachum, Roberto Badinter, João Clemente Baena Soares, Gro Harlen Brundtland, Mary Chinery-Hesse, Gareth Evans, David Hannay, Enrique Iglesias, Amre Moussa, Satish Nambiar, Sadako Ogata, Yevgeny Primakov, Qian Qichen, Nafis Sadik, Salim Ahmed Salim e Brent Scowcroft. 50 ORGANIZAÇÃO DAS NAÇÕES UNIDAS. Painel de Alto Nível das Nações Unidas sobre Ameaças, Desafios e Mudança. A More Secure World: our shared responsibility. Nova Iorque: Nações Unidas, 2004. Disponível em: <http://www.un.org/en/peacebuilding/pdf/historical/hlp_more_secure_world.pdf>. Acesso em: 17 jul. 2015. 
internacionais por meio de ações como a mediação, ou mesmo a aplicação de sanções. Havia também grande preocupação com a legitimação do uso da força para situações em que não haveria soluções pacíficas de controvérsias. O conceito de soberania também foi questionado, assim como a aplicação R2P em casos específicos.

Assim, ante estes acontecimentos, os debates sobre o R2P foram retomados para constarem na pauta da Cúpula Mundial (World Summit), ocorrida em 2005, que contou com expressivo número de Chefes de Estado e Governo de várias partes do mundo. A adoção do texto referente ao Documento Final da Cúpula Mundial se deu de maneira unânime, o que obviamente inclui os parágrafos 138 e 139, relativos à consolidação do R2P. Neles, estão estabelecidos os fundamentos básicos do conceito, que se diferencia do direito de ingerência ao restringir escopo de atuação internacional das intervenções sob o R2P aos crimes de guerra, genocídio, crimes contra a humanidade e limpeza étnica ${ }^{51}$.

A exemplo do relatório do ICISS, o Documento Final da Cúpula Mundial considera que o R2P se relacionaria com as discussões de segurança humana ao colocar o Estado como o primeiro responsável pela proteção de sua população, e não só de suas fronteiras. Contudo, os documentos se diferenciam de outras maneiras, pois o resultado final da Cúpula Mundial limitou a aplicação do R2P, mas franqueou a possibilidade de participação de organizações regionais na sua implementação. O estabelecimento de limites para atuação internacional no âmbito do parágrafo foi tema de extensas negociações visando evitar a ampliação do R2P para que outros crimes fossem abrangidos. Para a diplomacia brasileira, por exemplo, caso houvesse outras causas para intervenção abarcadas pelo R2P, a responsabilidade de proteger se assemelharia ao dever de ingerência, abrindo possibilidades para servir de justificativa para as mais diversas intervenções, não necessariamente humanitárias ${ }^{52}$.

Todavia, conforme o Documento Final da Cúpula Mundial, é reconhecido que as responsabilidades de prevenir e proteger são estendidas à comunidade internacional nas situações em que haja negligência ou incapacidade do Estado em fazê-lo. Primeiramente, caso se verifique tal comportamento estatal, soluções pacíficas de controvérsia devem ser tentadas ou pelo menos idealizadas, de acordo com o disposto nos capítulos VI e VIII da

51 ORGANIZAÇÃO DAS NAÇÕES UNIDAS. World Summit Outcome. 2005. Disponível em <http://www.who.int/hiv/universalaccess2010/worldsummit.pdf〉. Acesso em: 12 Jun. 2015.

${ }_{52}$ BIERRENBACH, A. M. O conceito de responsabilidade de proteger e o Direito Internacional Humanitário. Brasília: FUNAG, 2011, p. 159.

forem ou parecerem ser insuficientes, de acordo com o que estabelece o Capítulo VII da Carta 
da ONU, por meio da ação do Conselho de Segurança. O texto ainda reforça o comprometimento dos Estados membros em auxiliar seus pares a desenvolver sua própria capacidade de proteção, retomando o conceito de prevenção intrínseco ao R2P, o que dotaria o Estado de capacidade para tomar medidas antes mesmo de um conflito eclodir ${ }^{53}$.

Após o término do mandato de Kofi Annan e da eleição de Ban Ki-moon, o R2P continuou como tema prioridade para o Secretariado e na pauta de discussões da Assembleia Geral. Em janeiro de 2009, no relatório intitulado Implementing the Responsibility to Protect $^{54}$, Ban Ki-moon estipulou três pilares para a sustentação das bases do conceito de R2P. O primeiro pilar versaria sobre a responsabilidade primária do Estado na proteção de sua população; o segundo, sobre a responsabilidade internacional de apelar a vias pacíficas para proteção da população dos Estados envolvidos; o terceiro pilar possibilita a ação coletiva internacional quando da incapacidade do Estado e dos meios pacíficos de solução internacional. O terceiro pilar abre espaço para controvérsias no âmbito internacional, retomando a discussão anterior à formalização do conceito de que a responsabilidade de proteger abriria margens à ingerência entre Estados. A controvérsia se daria também porque alguns Estados não estão dispostos a aceitar qualquer tipo de uso da força militar que não fosse aprovada pelo Conselho de Segurança, nem em casos de intervenção humanitária ${ }^{55}$.

No âmbito da Assembleia Geral, foi adotada a Resolução $63 / 308^{56}$, pela qual os Estados assinalaram sua intenção de continuar a discutir o tema. Em resposta, Ban Ki-moon produziu o relatório de 2010 Early Warning, Assessment and Responsibility to Protect ${ }^{57}$, que contribuiu para o debate ao centrar esforços no incentivo da adoção de medidas preventivas capazes de prevenir atrocidades. Os debates informais que se seguiram enfatizaram a necessidade de avisos prévios aos Estados antes que ações efetivas fossem postas em prática.

53 ORGANIZAÇÃO DAS NAÇÕES UNIDAS. World Summit Outcome. 2005. Disponível em <http://www.who.int/hiv/universalaccess2010/worldsummit.pdf>. Acesso em: 12 Jun. 2015.

54 BAN, K. M. Report of the Secretary General - Implementing the Responsibility to Protect. 2009. Disponível

<http://www.responsibilitytoprotect.org/index.php? module=uploads\&func=download\&fileId=655>. Acesso em: 12 Jun. 2015.

${ }_{55}$ BIERRENBACH, A. M. O conceito de responsabilidade de proteger e o Direito Internacional Humanitário. Brasília: FUNAG, 2011, p. 159.

${ }^{56}$ ORGANIZAÇÃ̃ DAS NAÇÕES UNIDAS. Assembleia Geral. Resolução 63/308. Adotada na $63^{a}$ sessão. Disponível em: <http://responsibilitytoprotect.org/Resolution\%20RtoP(3).pdf >. Acesso em: 12 Jun. 2015.

57 BAN, K. M. Report of the Secretary General - Early Warning, Assessment and the Responsibility to Protect. 2010. Disponível em: 〈http://www.globalr2p.org/media/files/2010_a64864.pdf〉. Acesso em: 12 Jun. 
Em 2011, outro relatório de Ban Ki-moon, The Role of Regional and Subregional Arrangements in Implementing the Responsibility to Protect ${ }^{58}$ foi submetido a questionamentos em que participaram 43 Estados-membros, 3 organizações regionais e 4 representantes da sociedade civil. O principal desafio verificado na ocasião foi referiu-se à cooperação e ao financiamento das operações de R2P em tempos de crise econômica, bem como foi evidenciado o valioso trabalho que pode ser prestado por organizações regionais na prevenção de massacres e outras massivas violações aos direitos humanos ${ }^{59}$.

Em 2012, no relatório Responsibility to protect: timely and decisive response ${ }^{60}$, também de Ban Ki-moon, as conversações que ocorreram em 5 de setembro daquele ano se deram em torno do terceiro pilar do R2P, bem como acerca das possibilidades de medidas coercitivas e não coercitivas a serem usadas como resposta coletiva da sociedade internacional frente a afrontas aos direitos das populações locais. Em 11 de setembro de 2013, as discussões ocorreram com base na resolução Responsibility to Protect: State responsibility and prevention, de autoria do Secretário-Geral ${ }^{61}$.

É importante destacar que, em 2006, o Conselho de Segurança reafirmou seu comprometimento perante o R2P em adotando a primeira resolução sobre o tema, a de número 1674, o que foi confirmado pela resolução 1894, de 2009. Em casos específicos, Darfur, Líbia, Costa do Marfim, Iêmen, Mali, e Sudão e Sudão do Sul são exemplos de operações determinadas pelo Conselho de Segurança que se utilizaram do R2P para sua implementação. No caso do Quênia, foi pedida a ajuda do Conselho de Segurança e depois concordado com a atuação do Secretário-Geral para dirimir os conflitos no país. No total, até o presente momento, 25 resoluções e 6 pronunciamentos presidenciais fizeram menção ao R2P, sendo que 21 dessas resoluções foram adotadas após 2011, o que indica a assimilação da teoria está tendo desde sua adoção pela ONU. Outros casos, em que o conceito de R2P

${ }^{58}$ BAN, K. M. Report of the Secretary General - The role of regional and subregional arrangements in implementing the responsibility to protect Report of the Secretary-General. 2011. Disponível em: <http://www.globalr2p.org/media/files/2011_a65877.pdf>. Acesso em: 12 Jun. 2015.

${ }^{59}$ INTERNATIONAL COALITION FOR THE RESPONSIBILITY TO PROTECT. Interactive dialogue of the UN General Assembly on the role of regional and subregional arrangements in implementing the Responsibility to Protect. 21 jul. $2011 . \quad$ Disponível em: <http://responsibilitytoprotect.org/ICRtoP\%20Report\%20on\%20RIGO\%20GA\%20dialogue\%20on\%20RtoP\%2 OFINAL(1).pdf>. Acesso em: 12 Jun. 2015.

60 BAN, K. M., Report of the Secretary General - Responsibility to protect: timely and decisive response. 2012.

em:<http://www.responsibilitytoprotect.org/UNSG\%20Report_timely\%20and\%20decisive\%20re

Disponível sponse(1).pdf>. Acesso em: 8 Jun. 2015.

6 BAN, K. M. Report of the Secretary General - Responsibility to Protect: State responsibility and prevention. 2013. Disponível em: <http://www.globalr2p.org/media/files/n1338693.pdf>. Acesso em: 12 Jun.

${ }^{62}$ SHARMA, S. K.. The 2007-08 Post-Election Crisis in Kenya. In: HOFFMAN, J; NOLLKAEMPER, A. Responsibility to Protect: From Principle to Practice. Amsterdam: Pallas, 2012, p. 27-38. 
poderia perfeitamente se adequar, como na Síria, não foram apurados, o que denota a falta de objetividade na sua aplicação.

Esta situação tem sido denunciada por entidades da sociedade civil e grupos de Estados, como o Accountability, Coherence and Transparency Initiative (ACT), que propõe medidas que variem os métodos de tomada de decisões por parte do Conselho de Segurança, que possam, por exemplo, restringir o veto quando as situações analisadas envolvam massacres e graves violações aos direitos humanos. Contudo, apesar de seguir tratamento incongruente frente ao instituto, o Conselho de Segurança continua reafirmando o R2P em seus documentos oficiais. Em 16 de abril de 2014, o Conselho de Segurança adotou a resolução 2150 sobre a Prevenção e Luta contra o Genocídio, que determina a importância dos assessores especiais do Secretário Geral para a Prevenção do Genocídio e implementação do R2P. Outra resolução, adotada em 21 de agosto daquele mesmo ano pelo Conselho de Segurança, de número 2171, incluiu parágrafos sobre a operacionalização do R2P, reafirmando a responsabilidade em se proteger civis contra o genocídio, crimes de guerra, limpeza étnica e crimes contra a humanidade.

Nos anos seguintes à primeira aplicação considerada de sucesso do R2P, referente ao Quênia (2007 e 2008), a conceituação de R2P continuou a ser discutida. No entender de Sharma $^{62}$, a preocupação internacional com o conflito queniano, por exemplo, parece ter servido a interesses de grandes potências, que consideram importante a manutenção regional da segurança e o combate ao terrorismo, bem como para manter a situação caótica da Somália longe dos holofotes. Ainda, por hospedar um quartel-general africano das Nações Unidas, o Quênia tem peso estratégico no equilíbrio da segurança regional e o país costuma a se posicionar em favor das políticas adotadas principalmente pelos Estados Unidos para combate ao terrorismo. O impasse sírio, contudo, é emblemático para elucidar as limitações do R2P. A intervenção neste país, que não se daria a pedido do próprio Estado, como no caso queniano, ou que não tem a unanimidade do P5, como na situação da Líbia, evidencia a falta de acordo dos membros permanentes do Conselho de Segurança, o que inviabiliza uma intervenção com base no Responsibility to Protect ${ }^{4}$.

O Brasil é um dos países que dirigiu críticas ao R2P, principalmente sobre a ameaça à soberania que esta fundamentação poderia representar. Para apresentar um contraponto, defendeu uma nova definição de proteção internacional, o Responsability while Protecting (RwP), que tem suas bases no próprio R2P. Por meio dessa abordagem, a responsabilidade ao 
proteger visa alertar a sociedade internacional das possíveis implicações da intervenção armada, que muitas vezes pode ser mais agressiva para a população local do que a própria incapacidade do Estado ${ }^{63}$. Deste modo, haveria a ênfase no pilar da prevenção antes aos demais, havendo, portanto, uma hierarquização dos mesmos.

\section{CONCLUSÃO}

Este breve estudo procurou, modestamente, resumir em poucas linhas o trabalho do Secretariado e a atuação do Secretário-Geral no que diz respeito à implementação e consolidação da teoria do R2P no âmbito da ONU. Contudo, evidencia-se por meio deste estudo que, apesar de ser uma das ideias que se desenvolveu de maneira mais rápida nas relações internacionais recentemente, sua implementação é falha e demonstra a grande limitação dos poderes exercidos pelo Secretariado e pelo Secretário-Geral em relação aos Estados-membros da ONU, principalmente em relação aos países permanentes do Conselho de Segurança.

Contudo, os esforços para a consolidação teórica empenhados são reflexos das funções políticas exercidas pelo Secretário-Geral da ONU, que articula de acordo com os poderes recebidos pela Carta da ONU e pelos demais órgãos maneiras para conter a violência no cenário internacional. É importante salientar que o próprio conceito do R2P, que foi considerado uma alternativa à grande ingerência das intervenções humanitárias ocorridas no século passado, apresenta problemas, como os apontados pela diplomacia brasileira, sendo que estes tomam parte das discussões acerca de sua implementação e podem por em xeque o papel ocupado pela ONU perante as relações internacionais no que diz respeito à legitimidade do uso da força em relação a soberanias.

Dentre os erros que podem ser verificados no R2P, está a tentativa de consolidação de uma doutrina juridicamente objetiva sobre intervenções, porém evidentemente eivada de limitações politicas, econômicas e militares. Com base na segurança humana, as definições que estão sendo propostas ainda esbarram em questões atinentes a importância ou não do uso da força, do orçamento que pode ser dispensado em tais operações e na vontade política para sua implementação. Os diversos relatórios apresentados pelos Secretários-Gerais tendem a

${ }^{63}$ VIOTTI, M. L. Debate Aberto do Conselho de Segurança sobre Proteção de Civis em Conflito Armado. 2011. Disponível em: <http://www.itamaraty.gov.br/sala-de- imprensa/notas-aimprensa/conselho-de-segurancadas-nacoes-unidas-debate-aberto-sobre-protecao-de-civis-em-conflito-armado-nova-york-9-de-novembro-de2011/print-nota>. Acesso em: 12 Jun. 2015. 
salientar tais assuntos, mas alguns dos pontos levantados ainda parecem desconectados da realidade vivida por muitos países que se encontram em conflitos internos, que possuem motivações políticas, econômicas ou de outra ordem.

O conceito também é falho por não trazer mecanismos de responsabilização em caso de sua não aplicação ou de seu insucesso, o que torna inviável seu aproveitamento universal. Fica, portanto, a serviço do exercício do poder nas relações internacionais, não oferecendo critérios segurança jurídica, apesar de prometê-los. Também se salienta que esta tentativa de se admitir justas causas para intervenções não é, ao contrário de muitos de seus defensores entendem, algo novo, e pode ficar a mercê de interesses vários presentes no âmbito internacional. Esta nova roupagem, pretendida inclusive pelos Secretários-Gerais, faz parte do processo de manutenção da ONU como ator importante no debate sobre a soberania. Contudo, diante dos problemas atualmente enfrentados, que resultam em milhares de vidas perdidas e outros tantos de deslocados internos e refugiados que vivem em condições indignas em campos de refugiados, admite-se a relevância que tal instituto possa ter para promover critérios relativos à solidariedade e desenvolvimento.

Nesse mister, o papel do Secretariado e do Secretário-Geral é determinante tanto em razão das habilidades de se manter e adaptar a estrutura burocrática da organização em relação às demandas internacionais, quanto nas oportunidades aproveitadas em se ampliar poderes e atribuições. A sobrevivência da ONU para outros setenta anos dependerá das possibilidades de se manter eficiência e credibilidade no serviço público internacional ali prestado, bem como das possibilidades de gestão e articulação dos nomes que se seguirão no posto de Secretário-Geral.

\section{REFERÊNCIAS}

ALMEIDA RIBEIRO, Ana Cristina; BORGES, Leonardo Estrela. Art. 98. In. CALDEIRA BRANT, Leonardo Nemer. Comentário à Carta das Nações Unidas. Belo Horizonte: CEDIN, 2008, p. 1185-1120.

ANNAN, K. We the peoples: the role of the United Nations in the 21st Century. New York: United Nations, 2000.

ASMUSSEN, Jan. United Nations Peacekeeping Force in Cyprus (UNFICYP). In. KOOPS, Joachim; MACQUEEN, Norrie; TARDY, Thierry; WLIIAMS, Paul. The Oxford Handbook of United Nations Peacekeeping Operations. Oxford: Oxford University Press, 2015, p. 197209.

BAN, K. M. Report of the Secretary General - Early Warning, Assessment and the Responsibility to Protect. 2010. Disponível em: <http://www.globalr2p.org/media/files/2010_a64864.pdf>. Acesso em: 12 Jun. 2015. 
BAN, K. M. Report of the Secretary General - Implementing the Responsibility to Protect. $2009 . \quad$ Disponível em: $<$ http://www.responsibilitytoprotect.org/index.php? module=uploads\&func=download\&fileId $=655>$. Acesso em: 12 Jun. 2015.

BAN, K. M. Report of the Secretary General - Implementing the Responsibility to Protect. $2009 . \quad$ Disponível em: $<$ http://www.responsibilitytoprotect.org/index.php?module=uploads\&func=download\&fileId $=655>$. Acesso em: 12 Jun. 2015.

BAN, K. M. Report of the Secretary General - Responsibility to Protect: State responsibility and prevention. 2013. Disponível em: <http://www.globalr2p.org/media/files/n1338693.pdf>. Acesso em: 12 Jun. 2015.

BAN, K. M. Report of the Secretary General - The role of regional and subregional arrangements in implementing the responsibility to protect Report of the Secretary-General. 2011. Disponível em: <http://www.globalr2p.org/media/files/2011_a65877.pdf>. Acesso em: 12 Jun. 2015.

BAN, K. M., Report of the Secretary General - Responsibility to protect: timely and decisive response. 2012. Disponível em: <http://www.responsibilitytoprotect.org/UNSG\%20Report_timely\%20and\%20decisive\%20re sponse(1).pdf>. Acesso em: 8 Jun. 2015.

BAN, K. M., Report of the Secretary General - Responsibility to protect: timely and decisive response. 2012. Disponível em: <http://www.responsibilitytoprotect.org/UNSG\%20Report_timely\%20and\%20decisive\%20re sponse(1).pdf>. Acesso em: 8 Jun. 2015.

BIERRENBACH, A. M. O conceito de responsabilidade de proteger e o Direito Internacional Humanitário. Brasília: FUNAG, 2011, p. 159.

BORGES, Leonardo Estrela. Art. 97. In. CALDEIRA BRANT, Leonardo Nemer. Comentário à Carta das Nações Unidas. Belo Horizonte: CEDIN, 2008, p. 1160-1158.

CRETELLA NETO, José. Teoria Geral das Organizações Internacionais. São Paulo: Saraiva, 2007.

GINNEKEN, Anique H. M. Historical dictionary of the League of Nations. Lanham: The Scarecrow Press, 2006.

GORDENKER, Leon. The UN Secretary-General and Secretariat. 2 ed. Nova York: Routledge, 2010.

GUSTIN, M. B. S.; DIAS, M. T. F. (Re) Pensando a Pesquisa Jurídica: teoria e prática. 4. ed. Belo Horizonte: Editora Del Rey, 2013, p. 20-25.

INTERNATIONAL COALITION FOR THE RESPONSIBILITY TO PROTECT. Interactive dialogue of the UN General Assembly on the role of regional and subregional arrangements in implementing the Responsibility to Protect. 21 jul. 2011. Disponível em: <http://responsibilitytoprotect.org/ICRtoP\%20Report\%20on\%20RIGO\%20GA\%20dialogue \%20on\%20RtoP\%20FINAL(1).pdf>. Acesso em: 12 Jun. 2015. 
INTERNATIONAL COMMISSION ON INTERVENTION AND STATE SOVEREIGNTY. The Responsibility to Protect. Ottawa: International Development Research Centre, 2001. Disponível em: <http://responsibilitytoprotect.org/ICISS\%20Report.pdf>. Acesso em: 17 jul. 2015.

LIGA DAS NAÇÕES. Assembleia. Resolução A.32(1).1946.X. General report of the Finance Committee, approved by the Finance Committee. 18 abr. 1946.

LYNCH, Colum. The Race for U.N. Secretary-General is Rigged. Foreign Policy. 14. Nov. 2014. Disponível em: <http://foreignpolicy.com/2014/11/14/the-race-for-u-n-secretarygeneral-is-rigged/>. Acesso em: 12 jul. 2015.

MACMILlAN, Margaret. Paz em Paris: a Conferência de Paris e seu Mister de Encerrar a Grande Guerra. Trad. Joubert de Oliveira Brízida. Rio de Janeiro: Nova Fronteira, 2004.

MALANCZUK, Peter. Akhurst's Modern Introduction to International Law. 7 ed. Londres: Routledge, 1997.

MELESCANU, Théodore. Article 7. In. COT, Jean-Pierre; PELLET, Alain (coord.). La Charte des Nations Unies: commentaire article par article. 3 ed. Paris : Economica, 2005.

ORGANIZAÇÃO DAS NAÇÕES UNIDAS. Assembleia Geral. Convenção sobre os Privilégios e Imunidades das Nações Unidas. 13 fev. 1946. Disponível em: <http://daccessdds-ny.un.org/doc/RESOLUTION/GEN/NR0/032/73/IMG/NR003273.pdf?OpenElement>.

Acesso em 16 jun. 2015.

ORGANIZAÇÃO DAS NAÇÕES UNIDAS. Assembleia Geral. Resolução 11 (1). Terms of Appointment of the Secretary General. 24 jan. 1946. Disponível em: <http://daccess-ddsny.un.org/doc/RESOLUTION/GEN/NR0/032/62/IMG/NR003262.pdf?OpenElement>.

Acesso em: 12 jul. 2015.

ORGANIZAÇÃO DAS NAÇÕES UNIDAS. Assembleia Geral. Resolução 11 (1). Terms of Appointment of the Secretary General. 24 jan. 1946. Disponível em: <http://daccess-ddsny.un.org/doc/RESOLUTION/GEN/NR0/032/62/IMG/NR003262.pdf?OpenElement>.

Acesso em: 12 jul. 2015.

ORGANIZAÇÃO DAS NAÇÕES UNIDAS. Assembleia Geral. Resolução 13 (1). Organization of the Secretariat. 14 fev. 1946. Disponível em: <http://daccess-ddsny.un.org/doc/RESOLUTION/GEN/NR0/032/64/IMG/NR003264.pdf?OpenElement>.

Acesso em: 16 jun. 2015.

ORGANIZAÇÃO DAS NAÇÕES UNIDAS. Assembleia Geral. Resolução 46/59. Declaration on Fact-finding by the United Nations in the Field of the Maintenance of International Peace and Security. 9 dez. 1991. Disponível em: <http://www.un.org/documents/ga/res/46/a46r059.htm>. Acesso em: 12 jul. 2015. ORGANIZAÇÃO DAS NAÇÕES UNIDAS. Assembleia Geral. Resolução 49/233A. 23 dez. 1994. Disponível em: <http://www.un.org/es/comun/docs/?symbol=A/RES/45/248>. Acesso em: 15 jun. 2015.

ORGANIZAÇÃO DAS NAÇÕES UNIDAS. Assembleia Geral. Resolução 60/286. Revitalization of the General Assembly. 9 out. 2006. Disponível em: < http://www.securitycouncilreport.org/atf/cf/\%7B65BFCF9B-6D27-4E9C-8CD3CF6E4FF96FF9\%7D/SGE\%20ARES60\%20286.pdf>. Acesso em: 12 jul. 2015.

ORGANIZAÇÃO DAS NAÇÕES UNIDAS. Assembleia Geral. Resolução 63/308. Adotada na $63^{\mathrm{a}}$ sessão. Disponível em: <http://responsibilitytoprotect.org/Resolution\%20RtoP(3).pdf >. Acesso em: 12 Jun. 2015. 
ORGANIZAÇÃO DAS NAÇÕES UNIDAS. Painel de Alto Nível das Nações Unidas sobre Ameaças, Desafios e Mudança. A More Secure World: our shared responsibility. Nova Iorque: Nações $\quad 2004 . \quad$ Unidas, Disponível em: <http://www.un.org/en/peacebuilding/pdf/historical/hlp_more_secure_world.pdf $>$. Acesso em: 17 jul. 2015.

ORGANIZAÇÃO DAS NAÇÕES UNIDAS. World Summit Outcome. 2005. Disponível em <http://www.who.int/hiv/universalaccess2010/worldsummit.pdf>. Acesso em: 12 Jun. 2013.

ORGANIZAÇÃO DAS NAÇÕES UNIDAS. World Summit Outcome. 2005. Disponível em <http://www.who.int/hiv/universalaccess2010/worldsummit.pdf >. Acesso em: 12 Jun. 2015.

ORGANIZAÇÃO DAS NAÇÕES UNIDAS. World Summit Outcome. 2005. Disponível em <http://www.who.int/hiv/universalaccess2010/worldsummit.pdf〉. Acesso em: 12 Jun. 2015.

SALMON, Jean (ed.). Dictionnaire de Droit International Public. Bruxelas : Bruylant, 2001 apud CRETELLA NETO, José. Teoria Geral das Organizações Internacionais. São Paulo : Saraiva, 2007.

SHARMA, S. K.. The 2007-08 Post-Election Crisis in Kenya. In: HOFFMAN, J; NOLLKAEMPER, A. Responsibility to Protect: From Principle to Practice. Amsterdam: Pallas, 2012, p. 27-38.

VIOTTI, M. L. Debate Aberto do Conselho de Segurança sobre Proteção de Civis em Conflito Armado. 2011. Disponível em: <http://www.itamaraty.gov.br/sala-deimprensa/notas-aimprensa/conselho-de-seguranca-das-nacoes-unidas-debate-aberto-sobreprotecao-de-civis-em-conflito-armado-nova-york-9-de-novembro-de-2011/print-nota>.

Acesso em: 12 Jun. 2015. 